\title{
THE CONUNDRUM AND LEGALITY OF STAMP DUTIES COLLECTION IN NIGERIA
}

\author{
Abdulhamid Ellawule \\ Department of Accounting and Finance, Abubakar Tafawa Balewa University, Bauchi \\ Email: ellawule@yahoo.com
}

\section{Cite this article:}

Abdulhamid E. (2021), The Conundrum and Legality of Stamp Duties Collection in Nigeria. African Journal of Accounting and Financial Research 4(2), 11-25. DOI: 10.52589/AJAFR/BLSV21X1

\section{Manuscript History}

Received: 20 March 2021

Accepted: 17 April 2021

Published: 27 April 2021

Copyright $(\odot 2020$ The Author(s). This is an Open Access article distributed under the terms of Creative Commons AttributionNonCommercial-

NoDerivatives 4.0 International (CC BY-NC-ND 4.0 ), which permits anyone to share, use, reproduce and redistribute in any medium, provided the original author and source are credited.
ABSTRACT: The dwindling oil revenue to Nigeria necessitated the need to improve revenue generation. The Stamp Duties is seen as "a new gold", however, the crisis between the FIRS and NIPOST might pose a threat. The study examined the provisions of the Stamp Duties Act and some relevant laws to ascertain the agency with the jurisdiction to collect and administer duties in Nigeria. It was found that FIRS has the authority to manage and administer duties and other taxes in Nigeria and not NIPOST. It was recommended that tax laws should be harmonised and postage stamps and stamp duties should be clearly defined to avoid ambiguity.

KEYWORDS: Stamp Duties, FIRS, NIPOST 
African Journal of Accounting and Financial Research

ISSN: $2682-6690$

Volume 4, Issue 2, 2021 (pp. 11-25)

www.abjournals.org

\section{INTRODUCTION}

The payment of stamp duty in Nigeria is regulated by law which is the Stamp Duty Act of 2004 (Massajuwa \& Aidonojie, 2020), also, Stamp Duty came into being according to Bielu (2019) through the Stamp Duty promulgation. Every tax law has an agency to administer it clearly stated and in the case of Nigeria, the FIRS Establishment Act 2007 clearly stated the agency authorised to manage and administer tax laws and this is done for a role and function clarity, to avoid duplication of duties in different Ministries Departments and Agencies (MDAs) and equally to reduce friction between agencies.

When this is done, it helps reduce the cost of governance and make public service efficient. It is in this light that in 2011, the then President of Nigeria, Jonathan Goodluck constituted a committee headed by Oronsaye to recommend how to reduce duplication of duties in government MDAs (Mbamalu, 2020) however, 90 per cent of the recommendations were rejected. It was argued that Nigeria only attempts to reduce the cost of governance when the revenue from oil dwindles (Mbamalu, 2020).

The Act governing Stamp Duties in Nigeria was never dormant but there was no enforcement by the revenue agency, though, Nigerian Postal Service (NIPOST) is known historically for the production and sale of postage stamps (Idowu, 2020). The FIRS in 2020 states that the agency is committed to making stamp duties the next major source of revenue to finance the budgetary requirements of the federal government in the face of dwindling oil revenue (Obayomi, 2020). Achieving this aim is going to be difficult because recently, there have been issues and controversies concerning the interpretation and application of the Stamp Duty Act (Massajuwa \& Aidonojie, 2020) and the confusion surrounding the agency on the authority to collect and account for the stamp duties in Nigeria could affect the revenue generation from stamp duties. The lack of a review of the Stamp Duties Act for a long time caused nonenforcement of the Act by the collection agency and non-compliance by the duty's payers (Adebiyi \& Akinoso, 2020). According to Idowu (2020), the enforcement of the Act by FIRS generated controversy between the two agencies (Idowu, 2020) which lead to a series of social media postings on 2 August 2020 through the Twitter handle of the NIPOST, @ref_ng, by the head of the board of the agency, Maimuna Abubakar stating that their mandate of production and collection of stamp duties have been stolen from them by FIRS (BBC News Pidgin, 2020). 
African Journal of Accounting and Financial Research

ISSN: $2682-6690$

Volume 4, Issue 2, 2021 (pp. 11-25)

www.abjournals.org

In a reply, the FIRS through their verified account @ firsNigeria on 4 August 2020 argue that NIPOST could not differentiate between a postage stamp and stamp duties and emphasized that it is the responsibility of FIRS to collect and account for stamp duties in Nigeria.

The crisis between the NIPOST and FIRS escalated and the Senior Staff Association of Statutory Corporations and Government Owned Companies (SSASCGOC) threatened to go on strike if the government failed to intervene (Comms Week, 2020). There is, therefore, the problem of which agency has the legal backing to administer the Stamp Duty Act in Nigeria. This has allowed the researcher to analyse through the doctrinal method the laws that give authority to the agency to administer the tax laws in Nigeria.

\section{AN OVERVIEW OF STAMP DUTIES}

Stamp Duties are duties imposed on instruments - the instruments include every written document (Enigbokan, Clever \& Kajola, 2014). Stamp Duties was introduced to Nigeria by the British Colonial Government through Ordinance 41 of 1939 and was formalised as the Stamp Duties Act No.5 of 1939 (Idowu, 2020). Stamp Duties Act has been amended so many times and is presently governed by the Stamp Duties Act S8, LFN 2004 which has also been amended by the Finance Act of 2019 and Finance Act of 2020. Besides the revenue generation from the duties, the objective of stamp duties is;

Except as aforesaid and subject to the provisions of section 90 (3) of this Act, an instrument executed in Nigeria, or relating, wheresoever executed, to any property situate or to any matter or thing is done or to be done in Nigeria, shall not, except in criminal proceedings, be given in evidence, or be available for any purpose whatsoever, unless it is duly stamped under the law in force in Nigeria at the time when it was first executed [Section 22(4), Stamp Duties Act 2004].

According to Enigbokan et al. (2014), there are two forms of stamp duties; fixed and advalorem. Fixed Duties are duties that do not vary with the consideration for the document being stamped and the examples of the instruments being assessed by fixed duties are Payment receipt; Guarantor forms; Bank notes or bills payable at sight; Proxy forms; Cheque leaves; 
African Journal of Accounting and Financial Research

ISSN: $2682-6690$

Volume 4, Issue 2, 2021 (pp. 11-25)

www.abjournals.org

Admission as Solicitor or Notary Public. Ad-valorem are duties that vary with the amount of consideration and are based on the rates determined by the Act. In calculating the duties, the Commissioner of Stamp Duties or adjudicator needs to know the amount involved in the transaction. This will enable him to determine the appropriate duty to be paid. The examples of instruments that are assessed based on an ad-valorem basis are Bills of exchange; Companies' share capital; Promissory notes; Mortgage and Debenture loans; Property valuation; Share Capital of Companies (Enigbokan et al., 2014).

Part II of the Stamp Duties Act explained the Instruments that are required by law and the instruments are Leases; Contract Notes; Bills of Lading; Duplicates and Counterparts; Agreements; Marketable Securities; Mortgages; Policies of Insurances; Letters of Powers of Attorney and Voting Papers; Receipts; Settlements; Share Warrants; Warrants for Goods; Appraisement; Notarial Acts; Instrument of Apprenticeship; Bank Notes, Bills of Exchange and Promissory Notes; Conveyances of Sale; Other Conveyances; Exchange Partition or Division; and Capital of Companies.

In achieving the objective of the study, the study compares what is obtainable in other countries with world best practices in the management and administration of taxation. The three countries selected are countries with good tax compliance and high tax-to-GDP ratio; the UK, US, and Seychelles.

\section{The UK Tax Administration}

In 2005, the HM Revenue and customs was established by the commissioners for Revenue and Customs Act (CRCA) 2005 to replace the Inland Revenue and Customs Excise (UK Tax, 2021). It is established by the Act of Parliament vested with the responsibility for the administration of the tax system in the UK. They maintain and implement the treasury tax policy. According to UK Tax (2021), the following are the functions of HM Revenue and customs: Ensure the safe flow of money to the Exchequer through collection compliance and enforcement activities; Ensure efficient public service management through the provision of funds; Protection of UK economy by facilitating legitimate international trade; Protect the UK fiscal, economic, social and physical security; Administer statutory payments - sick pay and 
African Journal of Accounting and Financial Research

ISSN: $2682-6690$

Volume 4, Issue 2, 2021 (pp. 11-25)

www.abjournals.org

statutory maternity pay; supports families financially through tax credits; Administer child benefits; Aim to administer the tax system in the most simple, customer-focused and efficient way.

The revenue agency administers Income tax; Corporation Tax; Capital Gains Tax; Inheritance tax; Insurance premium tax; Stamp; Land and petroleum revenue taxes; Environmental taxes; Climate change and aggregates levy and landfill tax; Value Added Tax (VAT), including import VAT; Customs duties; Trade statistics; National insurance; Tax credits; Child benefit; Enforcement of the national minimum wage; Recovery of students' loan repayments. The revenue agency is faced with three priorities: ensure prompt collection of revenue due to reduced tax avoidance and evasion; helps the customers in tax transformation and payment; and design and deliver a professional, efficient and engaged organisation.

\section{The US Tax Administration}

The revenue agency that administers tax in the US is the Internal Revenue Service (IRS). The agency manages and administers any tax laws enacted by Congress (Tax Policy Center, 2021). IRS performs three main functions: Processing of tax returns; Taxpayer service; and Enforcement. The agency generates almost 96 per cent of the funds needed to support federal operations (Bailey, 2021). To achieve the aim of the agency, different people with different skills and backgrounds are needed. The agency is structured for better service and the skills needed to go beyond accounting and legal positions. There are criminal investigation and compliance positions, and in other positions such as information technology, human capital, facilities management and other important positions to attain success (Bailey, 2021). Also, to attain compliance success, a substantial percentage of the budget of the agency is spent on examination and audits. 
African Journal of Accounting and Financial Research

ISSN: $2682-6690$

Volume 4, Issue 2, 2021 (pp. 11-25)

www.abjournals.org

\section{The Seychelles Tax Administration}

The Seychelles Revenue Commission (SRC) is the revenue agency responsible for the administration and collection of tax revenues (SIB, 2021). The agency administers the following taxes: Business Tax; Presumptive Tax; Value Added Tax; Income and NonMonetary Tax; Corporate Social Responsibility Tax; Immovable Property (Foreign-Owned) Tax; and Tourism Marketing Tax.

Seychelles is not the only country in Africa with high corporation tax, yet it has the highest tax-to-GDP ratio at 32.4 per cent. The Seychelles tax system is chosen to see how the tax agency has such a high tax-to-GDP ratio compared to other African countries. However, despite recent reforms to reposition the tax agency for better performance OECD (2020) states that the Business Tax of the country needs to be fairer and sustainable. Only 30 companies accounting for almost 80 per cent of Business Tax payments. OECD (2020) claims this is possible because of the special treatment of some companies by sighting their business headquarters outside and perpetuate tax evasion by not reporting accurately their business activities. It is recommended that Seychelles should broaden their VAT tax base, modernise Personal Income Tax and strengthen environmental-related taxation through the introduction of low-rate and broad-based carbon tax. Efforts should be made to improve administration for better tax collection and reducing taxpayers' burden. To improve tax compliance, the revenue commission introduced presumptive tax through simplification of the tax regime. This helps small businesses with an annual turnover of below a certain threshold.

\section{DISCUSSION ON THE POWER TO COLLECT STAMP DUTIES}

In launching a postage stamp to commemorate the country's independence, the Minister for Communication and Digital Economy, Isa Pantami states that the Nigerian Postal Service has been recognised as the government agency with statutory and historical authority for the production and collection of Stamp Duty (Olisah, 2021).

The confusion came up as a result of a lack of a clear definition and clarity between postage stamp, adhesive stamp and stamp duties. This is why the head of FIRS, Muhammad Nami, 
African Journal of Accounting and Financial Research

ISSN: $2682-6690$

Volume 4, Issue 2, 2021 (pp. 11-25)

www.abjournals.org

stated that the administrators in NIPOST cannot differentiate between these terms. Section 2 of Stamp Duty Act 2004 as amended defines stamp as an impressed pattern or mark using an engraved or inked die, an adhesive stamp, an electronic stamp, or an electronic acknowledgement for denoting any duty or fee, provided that the service shall utilise adhesive stamp produced by the Nigerian Postal Service under its enabling Act. The same Act defines duty as any stamp duty for the time being chargeable under this or any other Act and also includes any fee chargeable hereunder.

The Nigerian Postal Service Act defines postage stamp as any label, stamp, or stamped impression for denoting any rate of postage payable in respect of postal articles and includes adhesive postage stamps and stamps printed, embossed, or otherwise indicated on any envelope, wrapper, postcard, or another article, whether such postage stamp is issued under this Act or by the government of any foreign country.

Before any discussion on the legality of the agencies in administering taxes in Nigeria, let us highlight the functions and power of the NIPOST. Section 2 of the NIPOST Act states that the postal service shall have the exclusive privilege of:

a. Conveying all letters from one place to another where postal communication has been established; and

b. Performing all the incidental services of receiving, collecting, sending, dispatching and delivering, written and printed matter, parcels, and like materials, from one place to another, where postal communication has been established.

The function of the postal service is in section 4 of NIPOST Act 2004 which states that the functions of the postal service shall include to:

a) develop, promote and provide adequate and efficiently coordinated and economic postal services at fair and reasonable rates and fees;

b) maintain an efficient system of collection, sorting and delivery of mail nationwide;

c) provide various types of mail services to meet the need of different categories of mail users; and 
African Journal of Accounting and Financial Research

ISSN: 2682-6690

Volume 4, Issue 2, 2021 (pp. 11-25)

www.abjournals.org

d) establish and maintain postal facilities of such character and in such location consistent with reasonable economics as will enable the generality of the public to have ready access to essential postal services.

In exercising these functions, the Act gives power to the postal service in section 5. Section 5(c) states that the postal service to prescribe the number of postage stamps and how it is to be paid and 5(d) to provide postage stamps and other stamped papers, cards, and envelopes and to provide such other evidence of payment of postage and fees as may be necessary or desirable. Section 34(1) of the NIPOST Act gives the Postmaster-General the power to issue the instruments as per section 5(d). This is seen as being given the power to administer Stamp Duty, however, Bielu (2019) states that the power to legislate with regards to the tax collection between federal and state government is given to the National Assembly by the 1999 constitution as amended and section 4 of Stamp Duty Act 2004.

Highlighted here are some sections from the Stamp Duty Act and FIRS Establishment Act 2007 to establish the agency with the authority to collect stamp duties in Nigeria,

1. Section 4(1) of Stamp Duty Act of 2004 as amended states that the Federal Inland Revenue Service shall be the only competent authority to impose, charge and collect duties upon instruments specified in the schedule to this Act if such instrument relates to matters executed between a company and an individual, group or body of individuals. Subsection 2 of this section states that the relevant tax authority in the state shall collect duties in respect of instruments executed between persons or individuals at such rates to be imposed or charged as may be agreed with the Federal Government.

2. The amendment of section 89 of the Stamp Duty Act by the Finance Act 2020 by the insertion of section 89A buttresses the point that FIRS has the power to impose stamp duty. Section 89A (1) states that there is imposed a levy to be known as Electronic Money Transfer Levy, on electronic receipt and transfer for money deposited in any money deposit bank or financial institution, on any type of account. Subsection 2 of the section states that a levy shall be imposed as a singular and one-off charge of $\$ 50$ on electronic receipts or transfer of money for $\$ 10,000$ or more. The power to impose this levy is on subsection 3 of this section which states that The Minister of Finance shall, 
subject to the approval of the National Assembly, make regulations for the imposition, administration, collection and remittance of the levy. The power is vested on the minister supervising the FIRS and not the minister supervising NIPOST, communication and digital economy as now directed.

3. Furthermore, the power of FIRS to administer tax in Nigeria is in section 8 of the FIRS Establishment Act 2007. The section states the functions of the revenue agency as:

1) The service shall:

a. assess persons including companies, enterprises chargeable with tax;

b. assess, collect, account and enforce payment of taxes as may be due to the Government or any of its agencies;

c. collect, recover and pay to the designated account any tax under any provision of this Act or any other enactment or law;

d. in collaboration with the relevant ministries and agencies, review the tax regimes and promote the application of tax revenues to stimulate economic activities and development;

e. in collaboration with the relevant law enforcement agencies, carry out the examination and investigation to enforce compliance with the provisions of this Act;

f. make, from time to time, a determination of the extent of financial loss and such other losses by government arising from tax fraud or evasion and such other losses (or revenue foregone) arising from tax waivers and other related matters;

g. adopt measures to identify, trace, freeze, confiscate or seize proceeds derived from tax fraud or evasion;

h. adopt measures which include compliance and regulatory actions, introduction, and maintenance of investigative and control techniques on the detection and prevention of non-compliance; 
i. collaborate and facilitate the rapid exchange of information with relevant national or international agencies or bodies on tax matters;

j. undertake the exchange of personnel or other experts with complementary agencies for purposes of comparative experience and capacity building;

k. establish and maintain a system for monitoring international dynamics of taxation to identify suspicious transactions and the perpetrators and other persons involved;

1. provide and maintain access to up to date and adequate data and information on all taxable persons, individuals, corporate bodies, or all agencies of government involved in the collection of revenue for efficient, effective, and correct tax administration and to prevent tax evasion or fraud;

m. maintain database, statistics, records, and reports on persons, organizations, proceeds, properties, documents, or other items or assets relating to tax administration including matters relating to waivers, fraud, or evasion;

n. undertake and support research on similar measures to stimulate economic development and determine the manifestation, extent, magnitude, and effects of tax fraud, evasion, and other matters that affect effective tax administration and make recommendations to the government on appropriate intervention and preventive measures;

o. collate and continually review all policies of the Federal Government relating to taxation and revenue generation and undertake a systematic and progressive implementation of such policies;

p. liaise with the office of the Attorney-General of the Federation, all government security and law enforcement agencies, and such other financial supervisory institutions in the enforcement and eradication of tax-related offences; 
q. issue taxpayer identification number to every taxable person in Nigeria in collaboration with States Boards of Internal Revenue and Local Government Councils;

r. carry out and sustain rigorous public awareness and enlightenment campaign on the benefits of tax compliance within and outside Nigeria;

s. carry out oversight functions overall taxes and levies accruable to the Government of the federation and as it may be required, query, subpoena, sanction and reward any activities about the assessment, collection of and accounting for revenues accruable to the Federation; and

t. carry out such other activities as are necessary or expedient for the full discharge of all or any of the functions under this Act.

2) The Service may, from time to time, specify the form of returns, claims statements and notices necessary for the due administration of the powers conferred on it by this Act.

Subsection (1)(c) clearly states that the revenue agency has the power to collect, recover and pay to the designated account any tax under any provision of this Act or any other enactment or law, and subsection (1)(s) summarises the authority of FIRS in administering tax in Nigeria concerning other agencies of government by stating that it carries out oversight functions on overall taxes and levies accruable to the government of the federation and as it may be required, query, subpoena, sanction and reward any activities about the assessment, collection of and accounting for revenues accruable to the Federation. This is in line with the practices in countries earlier highlighted in this study.

The minister might have fought for the transfer of the administration of Stamp Duty to NIPOST but from various sections of Nigeria Tax Laws, it shows that FIRS has the sole authority to collect Stamp Duty. Also, "the alleged right or power of the Nigerian Postal Service to manage and collect stamp duties which was derived from the non-existent provision of NIPOST and Stamp Duty Acts was declared by the court not to align with the extant law (Bielu, 2019: p75)"'. Despite the conundrum, the charge of duty upon instruments is in sections 4 and section 89A 
African Journal of Accounting and Financial Research

ISSN: 2682-6690

Volume 4, Issue 2, 2021 (pp. 11-25)

www.abjournals.org

which give jurisdiction of Stamp Duties Act to FIRS and the relevant states Internal Revenue Service, and section 8 of the FIRS Establishment Act 2007 which also gives jurisdiction to administer all taxes in Nigeria to FIRS. The administration of Stamp Duty has always been the Federal Inland Revenue Service (FIRS) and not NIPOST. The finding of the study confirms the outcome of an earlier study by Bielu (2019).

\section{CONCLUSION}

The non-review of the Stamp Duties Act for decades created a lack of enforcement from the tax authority and non-compliance on the part of taxpayers. This has created controversy on which agency has the authority to collect duties in Nigeria. The finding of the study shows that FIRS has the authority to administer Stamp Duties in Nigeria and not NIPOST. To avoid different agencies laying claims to power to administer tax laws, all tax laws should be harmonised and the agency responsible for a particular tax should be clearly stated. Also important is a clear definition of postage stamps and stamp duties to avoid ambiguity. 
African Journal of Accounting and Financial Research

ISSN: $2682-6690$

Volume 4, Issue 2, 2021 (pp. 11-25)

www.abjournals.org

\section{REFERENCES}

Adebiyi, O., \& Akinoso, E. (2020). Nigeria: Stamp Duties - Where does the liability lie? Retrieved from https://www.mondaq.com/nigeria/tax-authorities/1006754/stampduties-where-does-the-liability-lie

Bailey, R.D. (2021). Working for the IRS - A committed mission, people and country.

Retrieved from https://www.irs.gov/about-irs/working-for-the-irs-a-commitment-tomission-people-and-country

BBC News Pidgin (2020, August 4). FIRS and NIPOST: Stamp Duty palava make Nigerian goment agencies fight themselves for twiter (FIRS and NIPOST fight on social media over Stamp Duty). Retrieved from https://www.bbc.com/pidgin/tori-53654238

Bielu, K.J. (2019). The legality or otherwise of collection of stamp duties by Nigeria Postal Service (NIPOST). AJCAL, 3, 71-85

Comms Week (2020, August 5). SSASCGOC asks FG to intervene in FIRS, NIPOST Stamp Duty crisis. Communications Week. Retrieved from https://www.nigeriacommunicationsweek.com.ng/ssascgoc-asks-fg-to-intervene-in-firsnipost-stamp-duty-crisis/

Enigbokan, F., Clever, T. \& Kajola S. (2014) Introduction to taxation. Lagos: Institute of Chartered Accountants of Nigeria.

Idowu, A. (202). Insight: Nigeria's stamp duties conundrum. Retrieved from https://news.bloombergtax.com/daily-tax-report-international/insight-nigerias-stampduty-conundrum

Massajuwa, F.U., \& Aidonojie, P.A (2020). The Challenges of the plain and unambiguous legal interpretation of some of the provisions of Nigeria Stamp Duties Act. KIU Journal of Social Sciences, 6(3), 91-100

Mbamalu, M. (2020, May 6). Govt ejects 90\% of Orosanye report. The Guardian. Retrieved from https://guardian.ng/news/govt-rejects-90-of-oronsaye-report/ 
African Journal of Accounting and Financial Research

ISSN: 2682-6690

Volume 4, Issue 2, 2021 (pp. 11-25)

www.abjournals.org

Obayomi, W. (2020). FIRS provides clarification on the administration of stamp duties in Nigeria. Retrieved from https://home.kpmg/ng/en/home/insights/2020/07/firs-providesclarifications-on-administration-of-stamp-duties-in-nigeria.html

OECD (2020). Despite recent reforms Seychelles needs a fairer and more sustainable tax system. Retrieved from https://www.oecd.org/tax/despite-recent-reforms-seychelles$\underline{\text { needs-a-fairer-and-more-sustainable-tax-system-says-oecd.htm }}$

Olisah, C. (2021, March). NIPOST reclaim Stamp Duty collection from FIRS after years of dispute. Nairametrics. Retrieved from https://nairametrics.com/2021/03/11/just-innipost-reclaim-stamp-duty-collection-from-firs-after-years-of-dispute/

SIB (2021). Seychelles tax guide. Retrieved from https://www.investinseychelles.com/investors-guide/investor-resources/seychelles-taxguide

Tax Policy Center (2021). What does the IRS do and how can it be improved? Retrieved from https://www.taxpolicycenter.org/briefing-book/what-does-irs-do-and-how-can-itbe-improved

UK Tax (2021). HM Revenue and Customs: About us. Retrieved from https://www.gov.uk/government/organisations/hm-revenue-customs/about 
African Journal of Accounting and Financial Research

ISSN: 2682-6690

Volume 4, Issue 2, 2021 (pp. 11-25)

www.abjournals.org 